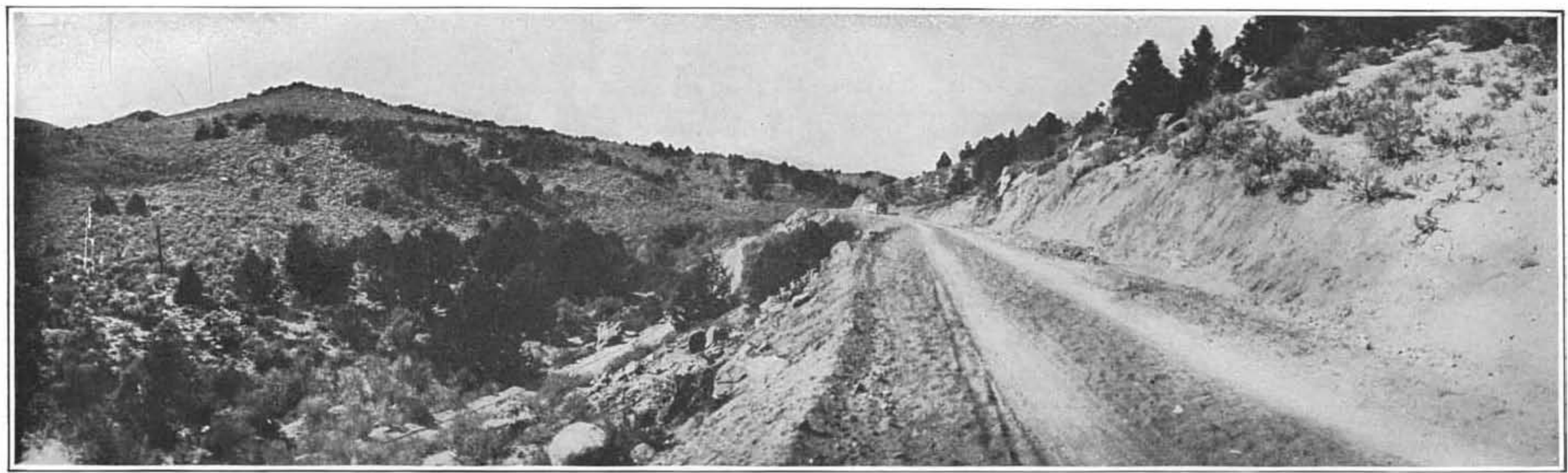

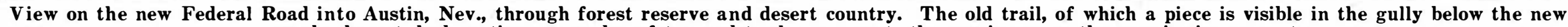
embankment, had continuous grades of ten and twelve per cent; the maximum on the new is six per cent

\title{
Tours and Detours
}

\section{Impressions of the Through Automobile Highways of the Eastern and Central States}

\section{By J. Malcolm Bird}

THE last word with regard to ultimate acceptability lies with the ultimate consumer. Our roads just as truly as anything else are an article of manufacture and use; the ultimate consumer is the man who uses them-driver of car, of truck, in less degree of horse Road building and maintenance, dead from 1917 to 1919, revived in 1920 and regained their health in 1921 During the past summer I have played the part of ultimate consumer over many roads, including some 2,000 miles of our main intersectional highways. In view of the prospect that 1922 will see even greater road activity than the past season, I venture to set down here my impressions, in the hope that some of them at leas will fall on ground not barren.

The outstanding feature of the present condition of our roads is the contrast between town and country. Over the entire length of the Mohawk Trail and less consistently on other routes, city lines are marked by signs informing the motorist that he is entering the corporate limits, that here state supervision of the road ceases. As a study in cause and effect these boards are admirable; as bearers of information they are superfluous. You drive for miles through open country over a velvet highway. Suddenly you are jounced and jerked over a dilapidated brick pavement, or pitched into and out of deep holes in prehistoric macadam, or made to vibrate to the alternate sharps and flats of a "block" pavement of which no two adjacent blocks by any chance strike the same level. No sign is needed to identify this as the city.

The reasons for the condition are obvious enough Perhaps the road is occupied by a traction line, bound by afranchise to keep the street in order. The natural disinclination to smooth the way for automotive competition is bolstered by the fact that the plea of semibankruptcy is uncomfortably close to the truth. And in the absence of a trolley company to act the villain, the city fathers, before appropriating $\$ 100,000$ for two miles of modern concrete on Main Street, demand to be shown just how and when and whence the money is coming back.

There are two angles to this situation. On one of them no sympathy is due the local obstructionists. If the merchants of a 20,000 town insist that a main street resemblint in general contour the devastated regions of France is good enough for them, they are probably right. For people who are satisfied with that kind of a street, that kind of a street is the most fitting reward I can imagine.

The local viewpoint, however, is not entirely wrong. It is not true that nobady from out of town has to use the street if he doesn't want to. In these days of broad interdependence, no community can withdraw into its shell and thus divorce itself from playing its part in the world's business. Cars and trucks from other parts of the state and from other states $d o$ have to use that street. But it is true that in proportion to the degree of such use, the local taxpayer may reasonably demand freedom from liability for the bills-until the happy time when every community keeps its street in good shape, putting the matter on a basis of perfectly even exchange.

In driving through seven states over a period of eighteen days, I saw at least twenty-eight different license plates. In one small town I counted eleven among fifty-odd cars parked about the public square Road commissions and automobile associations try to make the local people see that the money spent by these tourists pays for their use of the streets. But it takes a lot of gas at twenty-odd cents a gallon, vast numbers of tourists supplied with bed and board, a great volume of garage service, before the profits on these enterprises will match the cost of converting Main Street into a highway for transcontinental freight and passenger traftic.

Ultimately the matter will be dealt with by mandatory legislation, which will compel the recalcitrant communities to pay their share of the cost of fixing their streets for their own and for other people's use. Until such legislation is general it must be a matter for negotiation. Even on this basis it is not hopeless, if both parties will be reasonable. Announcement was recently made that arrangements had been reached for the reconstruction of the main street of Downington, Pa., "which in the past has been one of the worst stretches on the Lincoln Highway in the state." I saw concreting in progress, in the neighboring town of Coatesville, on what must have been a close rival of Downington for the place of ultimate dishonor. When Downington is fixed up there will be only one place in

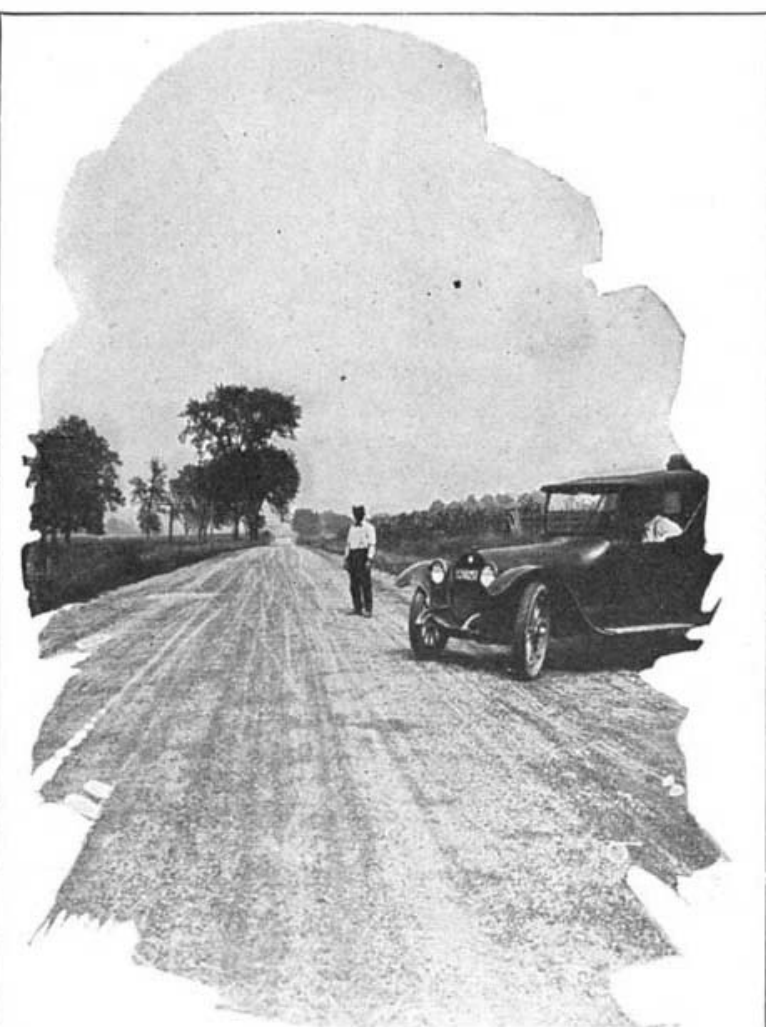

A perfectly maintained macadam section of the Lincoln Highway in Ohio the 350 miles between New Brunswick, N. J., and Uniontown, $\mathrm{Pa}$., where the motorist need feel seriously put out by bad city pavement-that awful quarter-mile on the outskirts of Morrisville, Pa.

Ohio, despite the fact that I broke a spring in one of its lake-front towns, is free from serious reproach in the matter of its Main Streets. Incidentally, I derived great spiritual consolation by limping ten miles to the next town to get that spring replaced. Indiana is in even better case than Ohio, so far as I saw it, though I did not cover so large a proportion of its territory. The Mohawk Trail is the prime offender: the good pavements of Batavia and Geneva stand out as oases in the drive from Buffalo to Albany. Among the smaller cities, I give the place of honor to Van Wert, O.; not alone its pavements, but every detail of the impression it makes on the tourist, is unusually fine. Erie, Pa., seems about the best of the cities of comparable size; one who has seen it only from the train will have difficulty in reconciling the thoroughly disreputable aspect which it there presents with the fine character of its residence and business streets. The same thing is true in less measure of Syracuse. Of the first-class cities, I have no hesitation in giving ranking position to Cleveland: I drove clear through, $f_{-\ldots}$. west to east, during the evening rush-hour, in considerably under an hour and with no bad going at all. To one accustomed to doing his city driving in New York and Newark this is a miracle.

I hope I will not be accused of sectional bias if I say a word in extenuation of Jersey City. Every motorist from out of town who has crossed any of New York's downtown ferries must have unpleasant memories of this part of his trip. But we ought to remember that with the big town just across the river, no driver is going to stop in Jersey City except in dire emergency, so that here more than anywhere else the complaint that good streets don't pay is justified. You do not have to drive through Jersey City to get to New York, however: go north from Newark, cut across through Hackensack and Englewood, and use the Dyckman Sfreet or the Ft. Lee Ferry. (The former shuts down during the winter months.) Better yet, go north before coming to Newark, and drive along the Watchung Mountains to Montclair or Paterson, and you will learn something about New Jersey scenery that does not seem to be generally known. I don't suppose the Lincoln Highway will ever be the best way of getting from New York to the Raritan River.

After bad pavement, the motorist's outstanding dread is the detour sign. Here again I am prepared to be reasonable. Roads wear out and have to be rebuilt; new knowledge makes it desirable to put down a type of roadbed that is less amenable than the old to construction without interrupting traffic. Few roads are wide enough to permit the contractor to establish himself on one side and leave the other open, with or without a flagman according to the length of the singletrack stretch. And the very fact that the road affected is the main line means that any route selected for the detour will be inferior.

All this is admitted. But during the early part of the last summer there was a detour out of Gettysburg 
on the Lincoln Highway seventy miles in length, over mountain roads built for the one-horse shay and never reconstructed. I drove into Mansfield, Ohio, from the east over bad dirt roads for forty miles-parallel with the Highway all the way and never more than two or three miles from it. I encountered a similar 30-mile detour into Erie from the west. It is respectfully submitted that there never was and never will be any justification for atrocities of this sort.

There is doubtless a certain amount of convenience to contractors and county authorities in closing, once for all, the entire length of road upon which operations are to be conducted during the current season. One can even imagine circumstances under which it might be similarly convenient to carry on work at severa isolated points, so distributed along the road as to close a stretch of many miles. But the convenience of county authorities and of contractors is not the only factor that ought to be considered; the convenience of those who are trying to use the roads should be weighed for what it is worth. The loss to truck and car owners through an unreasonable detour may far exceed the loss which would accrue to contractor and to the county past season. In this instance an effort was made to follow the procedure which I have outlined, confining the work to reasonable stretches of road at a given time and making the detour only long enough to circumnavigate the parts affected. I have been over this route several times during the past season, and have not found this detour any two times in the same place. This is fine; but it is rather discouraging to discover, after following it in its latest location for five miles, that the gentleman in charge of the relocation of the signs has got tired of his job, and after getting one nicely on to the thoroughly dilapidated Bristol road, has left one to blunder into Philadelphia by the side door, or to wander back to the Highway at an indeterminate point, as one best could. It doesn't do to shift the detour without shifting the signs. Whatever I might have had to say about detour signs per se is said by a contributor on another page.

There are certain radical differences between different sections of the country which come strongly to the attention of the visiting motorist. Here in the east we do not expect our roads to be straight, just so they ultimately arrive at the point to which they are sup-
The easterner who goes through the middle west and gets off the really big routes of travel, however, has one unpleasant surprise in store for him when he asks the way. The answer will invariably be "Keep right on the Pike; don't turn off." And within the next ten miles there will be anything from five to twenty places where there is a fork, both branches of which look exactly alike to the untutored eye. The native labors in the firm conviction that the "Pike" is stone and the other roads dirt, but if there is a distinction it is not visible to the eastern eye. I suffered from this, more than anywhere else, along the Colerain Pike, which runs across the Ohio hills from Wheeling to the Canton and Cleveland district, connecting there with the Lincoln Highway. As one goes west, the rectangular system of laying down the roads of course abates this nuisance considerably. A crossroads is not half as puzzling as a fork.

Another curious departure is found in the matter of the treatment of the garage help. My eastern readers would know better than to come back to a garage where they had taken on air or water without crossing the attendant's palm with silver. They would know

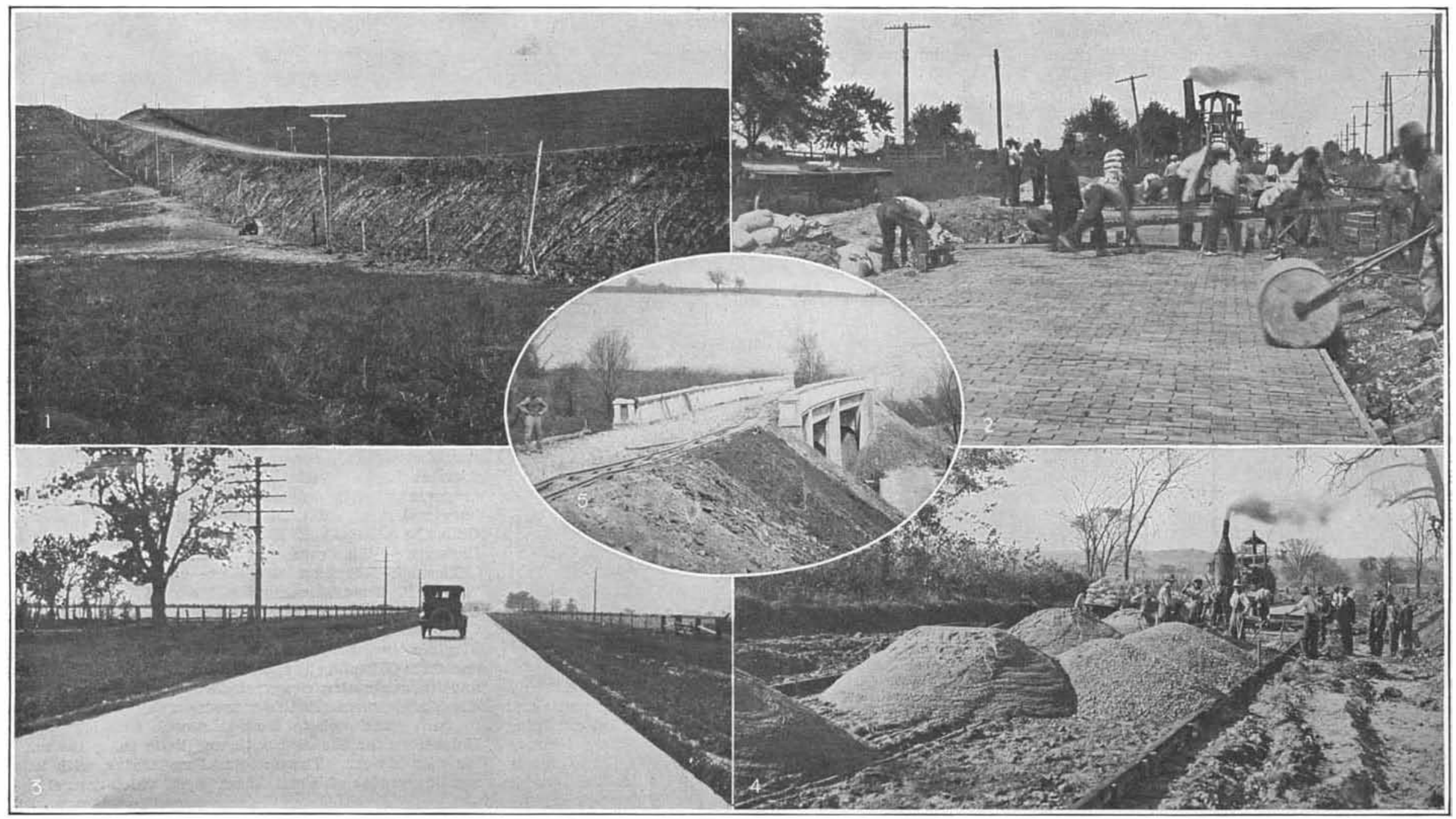

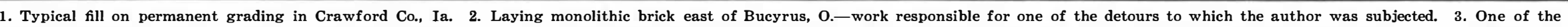

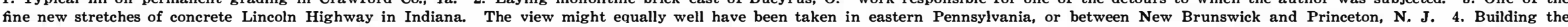

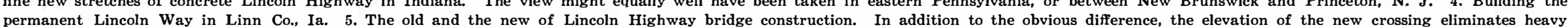

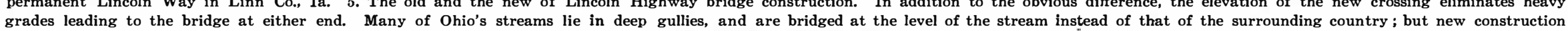
is gradually remedying this

Typical examples of the sort of engineering work that is going into the 1921 sections of the Lincoln Highway

treasury through a more rational distribution of the work. I cannot imagine conditions under which it would not be feasible to confine operations to a comparatively short stretch of the road at a time, concentrating a larger number of men on this stretch if this were desirable, so that at no time would it be necessary to close more than five or at the outside ten miles of the main road. In the presence of parallel roads-they are universally present in Ohio-this could not lead to detours of more than fifteen miles. In their absence, and under the greatest misfortune in the matter of intersecting roads, it should not in a settled country like Pennsylvania lead to a circuit of more than twentyfive miles : seldom to one so long. Incidentally, I should like to call Ohio's attention to the custom in New Jersey, where the rebuilding of a bridge is ordinarily preceded by the construction of a temporary crossing alongside the permanent site, before the old structure is demolished. This practice removes the last excuse for long detours.

A word of caution, however, may be inserted here, drawn from my observations of the detour that has existed between Trenton and Philadelphia during the posed to go. We run them around swamps, hills, hilllocks- the most trivial of obstacles, in fact. Throughout the middle west, with trifling exceptions, the roads run straight east-west and north-south, with at most a littl jog here and there to effect a more favorable crossing of a stream. This makes it impossible to get seriously lost. One has only to count the turns to be absolutely certain of one's direction. And one has but to watch the telephone wires to know whether one is approachin or receding from a town. If they thin out as you run past the widely spread houses you are leaving a town behind you. When they disappear altogether you are crossing the no-man's land between the district served by two consecutive towns. When you finally pass a house again and begin to pick up the poles with their wires, you are certain that you are approaching civilization once more. It may not be the town you want; if it is not, the worst thing possible is that you will have to turn north or south to that town. Getting completely off one's course and at loss for one's direction or location is out of the question. But the Ohio and Indiana drivers must have a tough time till they get used to the erratic behavior of the eastern roads. what reception to expect if they drove up to a strange garage and helped themselves to these commodities. In the central states you are always expected to help yourself.

The very air-stand is out on the curb, and there is no control cock that has to be opened indoors. I had to apologize to a garage hand in Wooster, O., to whom I innocently and as a matter of course offered a quarter after serving myself from his hydrant and airstand. They do not even charge, or expect a tip, for distilled water for your battery, as I learned to my further humiliation in Mansfield. And if there is anything to be done on the internals of your car, they are clad to have you hang around and watch them take it apart, offer advice and pump them for information, help them with recalcitrant bolts or other two-man jobs, and generally conduct yourself as though you wer one of the firm. The man from Ohio or Indiana wil have to tour the New York district before he can realize what a jolt all this is to the easterner.

The Lincoln Highway has been advertised until the average man has the impression that with the exception of a few final touches here and there it is prac- 


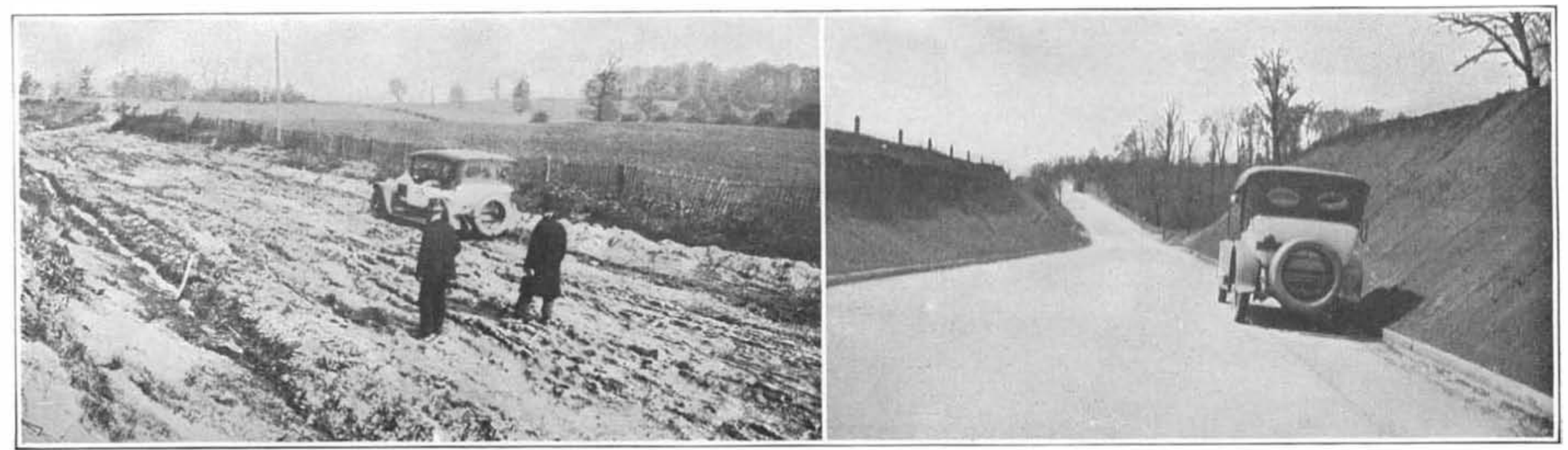

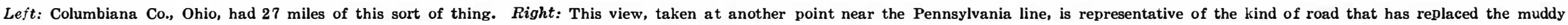
wagon trail of previous years.

Ohio roads before and after the 1921 campaign on the Lincoln route

tically finished and ready for use. I was the average man; I supposed that I could follow the pretty redwhite-and-blue markers clear to Chicago just as easily as I could follow them to Princeton, with no more serious obstacles than an occasional detour, and perhaps a few miles of inferior road here and there.

From New York to Gettysburg and from Lima to Chicago this expectation was borne out by the facts. In the region between Gettysburg and Lima-well, it wasn't. My advice to motorists for 1922 is emphatic. Stay off this part of the Lincoln Highway until some one who loves you has been over it, and assures you that it is in shape to travel on. When it is finished, so far as one can judge from what is being done to it in Pennsylvania and Ohio, the enthusiastic forecasts of a concrete thoroughfare from New York to Chicago will be abundantly realized. Till then it is no place for anybody to go in an automobile.

Between Gettysburg and Pittsburg the objection to the Highway in its present state is simple. Parts of the route have been concreted, in accordance with the program of the Pennsylvania Highway Commission. With respect to the other parts concreting is a matter of the future; it will presumably be done in the near future, and there is no particular reason to suppose that the detour issue will be handled any more intelligently than it was in 1921 . Until these links are concreted it is no kind of fun travelling them.

West of Pittsburg the situation is in general terms the same, but in its details it is far more annoying -at least, it was during 1921. In the first place, there isn't a single Lincoln Highway through Ohio. There are three or four places where the Highway has been or might have been or could be or where somebody wishes that it were: and all of these are marked with redwhite-and-blue stripes of one desimn or another. You can't cut the Gordian knot by following the latest style of marker, because for about 100 miles between Massilon and Upper Sandusky this would take you along a route that is barred by detour signs for practically its entire length. Of course I am here speaking of 1921 experience; I was on the Highway just four times over this stretch-in passing through Wooster, Mansfield, Galion and Bucyrus. The city limits invariably produced a detour that lasted till we were approaching the next city. Moreover, in at least one case the Association has allowed itself to be cajoled into marking two alternative routes with the latest model of 1921 standard markers.

The forty-mile stretch immediately east of Mansfield was a nightmare. Plainly marked det ours led to bridgeless bridges; detour signs ran out and left one to run for ten miles without guidance; one detour led along a concrete road in process of construction, on which the west bound car had to run off a four-inch curb on to a most disrepu-

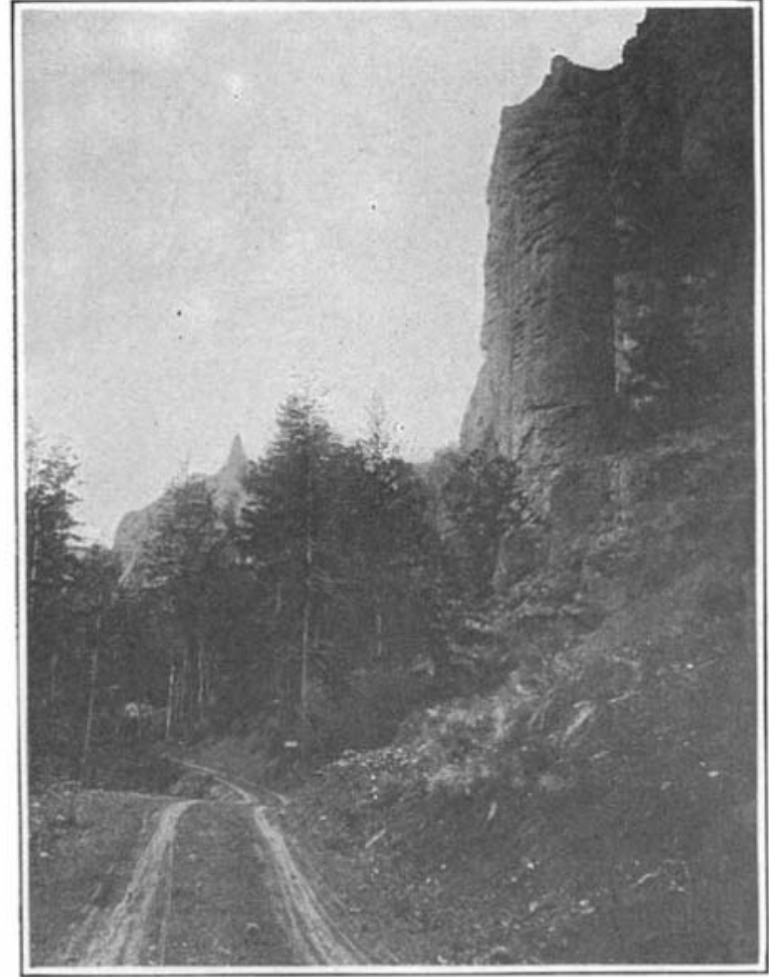

Mountain scenery on the transcontinental highway through Wyoming

table old wagon track to let eastbound cars pass; and in general, everything that road construction can bring out to plague the passing motorist was brought out to its full degree of possibility. I am informed that in the neighborhood of the Ohio-Pennsylvania line there is

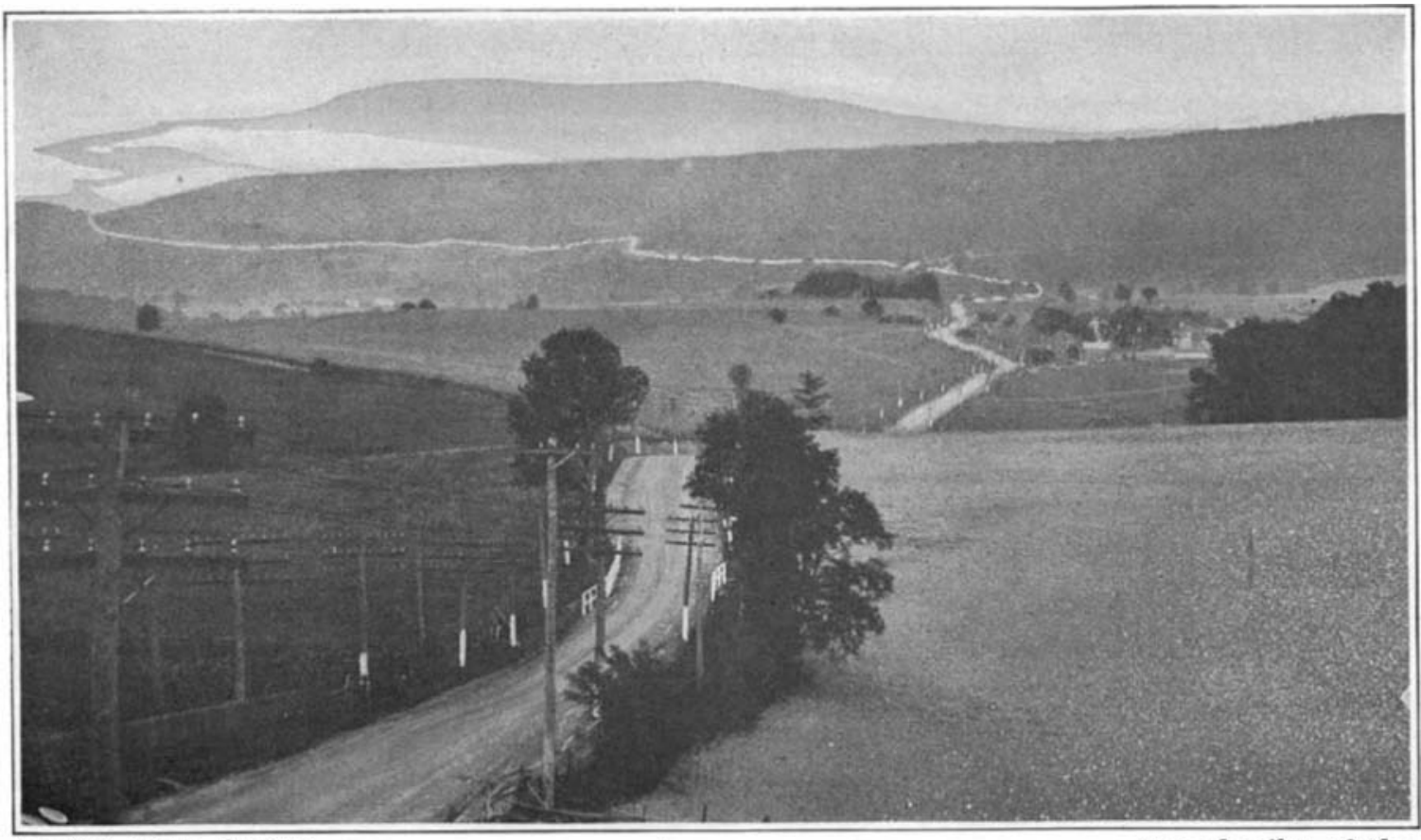

Another scenic feature of the coast-to-coast tour; a point in Pennsylivania where several miles of the the coast-to-coast tour; a point in Pennsylivania whe
Highway is visible winding among the hills ahead another gap of some miles of the same general character, with the exception that the detours are even orse.

The impression that I got in running through this barricade was that the route could not possibly be got into shape by the end of the season of 1921 . So I repeat; when the Lincoln Highway is finished it will be thoroughly good; but until you are assured by something more substantial than statements of the amount of money so far spent, you will best assume that it isn't finished, and aid in its ultimate completion by staying off it.

This leaves the question open of how to get across the country in an automobile. There are two ways, either of which, during 1921, was vastly to be preferred to the Lincolin Highway, and both of which lend the strong suggestion that their superiority will be more pronounced in 1922. The first involves using the Lincoln route as far as it is good-which is to say east of Gettysburg and west of Lima. If it is more convenient to pick up the northern loop of the Lincoln way (which leads here a double life), this can well be done at Upper Sandusky or any point west thereof, or perhaps as far east as Bucyrus. Between Gettysburg and the point where the main line is rejoined in Ohio, the old National Highway offers a route to which the most captious critic could offer no serious objection.

Through Maryland this route merits the adjective "superb." Superb in the condition of the road, clear through from Gettysburg via Waynesboro, Hagerstown, Cumberland, Uniontown, Washington (Pa.) to the West Virginia line, where twelve miles of bad road separate one from Wheeling; superb in its historic associations and its scenic attractions; and superb in its mountainclimbing features. In this connection the motorist ought to be warned not to leave Hancock bound west or Uniontown for the east with any little thing the matter with his car. These are real mountains, with long winding grades of 8 and 10 per cent, which compel the largest and most powerful cars to run largely in first speed and to stop half way up the longer pulls, to cool off and to permit the youth of the country to fill the radiators at 10 cents per fill. The highest elevation attained is Negro Mountain, a few miles west of Grantsville, Md. : 2,906 feet. The longest severe climb is three miles up Chestnut Ridge going east out of Uniontown; but going west, the road rises continually from Cumberland, 635 feet, to a point beyond Frostburg, 2300 feet. Nor is Cumberland the beginning; it is reached from the east only by severe climbs over at least two ridges, and less serious grades in profusion. And there are many double and triple curves of extreme sharpness. But the uniformly fine character of the road makes the trip a pleasure to anyone who is able to feel confidence in his car.

(Concluded on page 80) 


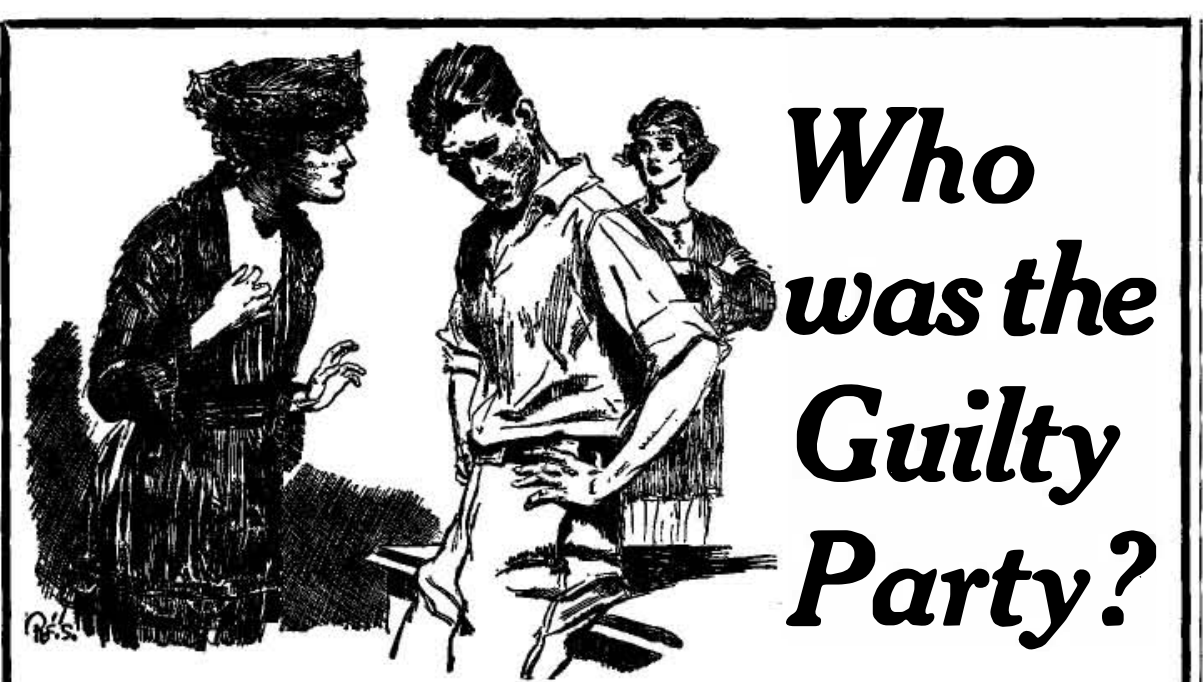

THEY had been engaged for months-soon they were to be married1 but on a crazy wager, he had gone out with this other woman-and Lizbeth had found him out!

Angry-jealous-her heart breaking with outraged love - who was to blame for what she did then? Women called her guilty - men called him guiltybut 0 . Henry-who understood women-who saw beneath the surface and found only a faint line between the angel and the sinner-O. Henry put the guilt far back in another place-

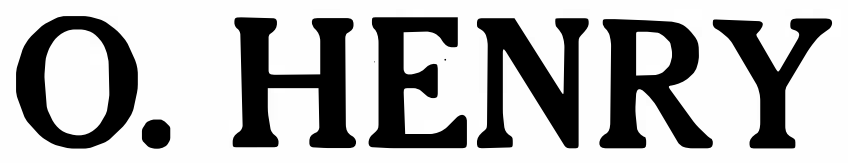

All over the world, from the great cities to the remotest corners, his name is known. His atories are on the stage, in the movies, in newspapers, bools and magazines. Collage Presidents acclaim his genius-the man on the street loves him for his Bible, as oft quoted as Shakespeare - in short, his stories are now an indispensable part of ebe library of everg well read mas.

Once in many generations a than is born
in whom burns the fire of heaven-th in whom burns the fire of heaven-the flames into the world like a meteror. The heaven-given fire is his and arges him on. Of such was $O$. Henry. He has the vision He' is the great teller of tales, and the power within him has given itself to the world in profusion and variety. He has given us more different kinds of wonderfull stories than anyone who ever livedthere isn't a single page that is not a livmen as though they were cased in glass.

variety in them as in ten different authors.

\section{OPPENHEIM $\underline{\underline{7 \text { Volumes }}}$ CR

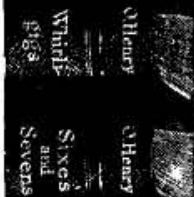 \\ Here are offered you, Free, such Masterpieces of Mystery; Adven- ture, I ove and International Intrigue, that they set your imagination afire and arouse the very best that is in you-stories of Courts and Empires, of Plots and Counter Plots, of State Secrets, Spies, Diplo- matic Intrigue, the rush and tumult of War, the intricate machinery of the Secret
and exciting. \\ While They Last!}

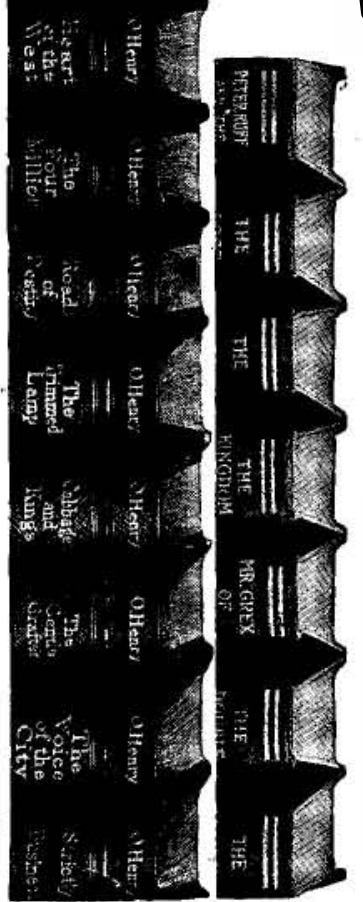

It happens that we have left over from last year's big sale a few hundred copies
of the best stories of $\mathrm{E}$. Phillips Oppenof the best stories of $E$. Phillips Oppen-
heim- -7 splendid volumes - the cream of present-day fiction. While they last, we will give one of these 7-volume sets FREE with each set of $O$. $;$ New York City sets are gone, vou will be able to ' Send me on ap-
get Oppenheim's thrilling tales
ony you, charges paid
only at their regular price in the book stores. Now, while you can, get your i of E. Phillips Ooppentheim with in silk cloth week, and the Oppenheim i days, and the 52.00 a munth week, and the Oppenteim is ior 9 months for the O. Henry
stories FREE! Never iset only and keep the ? volumes

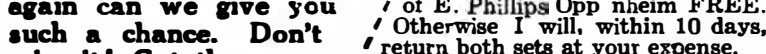
miss it? Cut the cous, ${ }^{\prime}$ return POD, and

THE REVIEW OF

$\therefore$ ADDREgS

REVIEWS CO. IThe mare sumptrous three-quarter Keratol 30 Irving Place i more a voclume and has proved a favorite. For

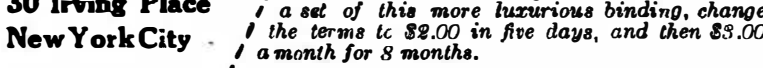

Tours and Detours

(Continued from page 8) To reach the west from wheeling the well-
advised motorist will steer clear of the Colerin Pike, which in the road books appears a the choice. Go on to Zanesville and Columbus, and then think of striking north; or if your destina-
tion lies in eastern Ohio turn north for Pittsburgh at the big crossroads a few miles beyond Uniontown-you can't miss it. The objections to
the Colerain Pike are, first, the rough surface and the Colerain Pike are, first, the rough surface and
the profusion of Joose stone; ; second, the extreme the profusion of loose stone; second, the extreme
difficulty of staying on it in the face of instructions to "follow the Pike ;" and third, the utter passed its head twice while looking for it: it never occurred to us that it could be anything but a billy-goat trail up the hill between the back stay on it and if you like sporty hilly going, you
will have a good deal of fun with the Colerain Pike. Mohawk Trail combined with the Albany Post Road gives a route of unusual merit from New
York to Buffalo. Except where it suffers from bad city pavements it is in extremely fine shape throughout: and it is so well marked that I followed it, without any guiding literature, clear
from Buffalo to New York, asking the way only once, when I found no other means of locating
the bridge at Albany. From Buffalo west along Lake Erie the route is a disappointment in the sense that it follows the Lake closely only here and there; and for 1921 there were three detours
of unnecessary length and, in two cases, of poor character. It looked as though these would be lifted by the end of the season, however, and the
only one that was really serious was the one of y one that was really serious was the one west
of Erie. From the state line into Cleveland the road is particularly satisfactory. West of Cleveland one can follow the Lake to Sandusky over
roads that are in first-class shape save in passing roads that are in first-class shape save in passing
through Huron; and from Sandusky one strikes southward to Bellevue; there rejoining an alternative road from Cleveland via Berea and Oberlin
which is likewise in good shape. The wise prowhich is likewise in good shape. The wise pro-
cedure is then to steer due west through Fremont. Bowling Green, Napoleon, Bryan, Butler, Ind. $\mathrm{e}$ c.o and join the Lincoln Highway at Goshen. Beyond Fort Wayne stick to the Lincoln Highway; the short cut to Chicago via Warsaw in-
cludes a lot of second-rate country road. If eral detours of from five to ten miles each in the interval between Fremont and the Indiana line are properly ironed out by the new year, as it
appeared they would certainly be, this will be the appeared they would certainly be, this will be the
best route between New York and Chicago for 1922, as regards road conditions alone.

922, as regards road conditions alone.
Returning to the subject of highway markings, a word may be said about the necessity for fixed system. There. is not much satisfaction in realizing, after driving three or four miles, that
the markers have ceased and that one must go back for the turn that was missed. A single
a pole at a street corner, a fork or a crossroads
means anything and therefore nothing. "Straight means anything and therefore nothing. "Straight
Through" may be indicated by poles on diagonally opposite corners, and "Turn" by poles set
squarely opposite one another in such a fashion that one must turn to pass between them. This procedure is open to two criticisms, however: the strange driver approaching on the side, road may be misled by the "Straight Through" arrange
ment to suppose that he is on the highway; and since the route runs in both directions, signs on
three out of four corners are necessary to indithree out of four corners are necessary to indicate completely a turn. Better, on think, is the
plan of putting a marked pole on the corner, and another a few yards beyond, on the straightahead road or around the corner, as the case may be. The driver then quickly forms the habit of never passing a possible turn until he has located the second pole. The sign on the
first pole may usually be so attached that its arrow gives the eye a very strong suggestion of
the direction in which to seek for the second one. the direction in which to seek for the second one. actual instructions for the steering hand it doesn't
and amount to much. But I should like to follow previous mention of the subject with the following
query, for the ears chiefly of Ohio road authorities: When two divergent roads each purport to be the Lincoln Highway, what is the motorist from another state to do about it?

As a final word I want to repeat the protest
which the SCrENTrFo AMERTCAN has several time which the SCIENTIFIO AMERTCAN has several times voiced against the promiscuous use of danger
signs. In Ohio and Indiana I saw curves posted as "sharp" and "dangerous" which were so wide that at any point on them I could see fifty yards or more around them. Coming across New York,
hills were posted as "steep" and "dangerous" down which I could coast only with my clutch free-they were not steep enough to overcome the compre sion if I left the gears in action. Such
misuse of warning signs can have no other re-
alt the the creation of a contempt for cautions sult than the creation of a contempt for cautions in the mind of the driver-and when he comes
to a place where the warning is really in order this is likely to be serious. The originator of the tale of "Wolf! Wolf!" was a psychologist

From Fasel to Cover (Continued from page 19)

Meanwhile the printing plate must be prepared. It consists of a sheet of rather thin aluminum,
the surface of which must be properly grained to the surface of which must be properly grained to
receive the transferred image. The graining is receive the transferred image. The grain by an
done by means of a rocking table, driven by electric motor. The table carries a large shallow
tank in which is placed the aluminum plate, cov- of special liguid The rocking action of the rock ing table causes a steady flow of marbles over in our eleventh sketch, with a resultant as shown

The next step takes us back to the thin sheets India paper carrying the impressions from the nc originals. These India paper sheets are now by means of little sharp-pointed steel tools. A light blow with the sharp-pointed tool causes the thin paper to stick to the heavy cardboard. The
sheets are mounted with due thought given to the gistering of the other companion plates of the me cover illustration. Various pieces of transfact, one is surprised to note the ingenious man$r$ in which the men engag $d$ in "sticking up the and other pieces of typography together.

The cardboard "form" being duly prepared, it placed face down on the aluminum plate, as
hown in our twelfth sketch, and passed through presg our twelfth sketch, and passed through ufficient pressure has been applied, the India paper transfer sheets are found to be firmly held moved with the aid of a moistened sponge, as
shown in our thirteenth sketch, leaving the inked mages on the aluminum. These images are successively etched by means of a sponge moistened ketch, and reinked, until a satisfactory mechaniAt this stage of

At this stage of the process. we have an alumiA taining four sets of images for the red, still another sheet containing the four sets of images

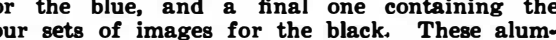
num sheets are now plac $d$ on different offset presses and clamped on the cylinders, as shown
in our fifteenth sketch. Obviously, the yellow plate receives yellow ink of the proper shade, the
red receives red ink, and so on. The "sticking u" of the cardboard form has been done in such a register when printed on to the same sheet of The principle of the offset press has already been described, and the essential details may be plate is held on one cylinder, and is inked by a t of ink rollers, and kept moistened by dainpening water rollers. The aluminum plate tranofers turn offsets the images on to the sheets of paper matic mechaniem. The offset press is capable of
matic as many as 4,000 to 5,000 impressions per hour, crers, printed "four up" or four sets of plates a a time, means a color is printed on 16,000 to
20,000 covers each hour. Naturally, four colors require four times the number of impressions. The offset process is peculiar in that it permits printing on coarse paper as well as highly coated must work with smooth paper in réproducing for this is that if too light a pressure is applied, only part of the half-tone dots print. If too much pressure is employed, the dot is emashed
nto the paper with a resulting muddy, heavy appearance. The usual method metheres employ a very coarse half-tone screen, 85 or even 65 lines to the inch. These screens will print dots are clearly on coarse paper, but naturally the high-class work. The offset process gives the fine coated paper to a rough antigue stock Incidentally, the best results are obtained. rough finished paper.

\section{The Planets}

Mereury is a morning star all through November, and is best visible on or about the time of his this time he is $10^{\circ} 27^{\prime}$ west of the sun, and rises more than an hour and a half before sunrise, so that he should be easily visible.

Mars is likewise a morning star, rising between three or four hours earlier than the sun.

Uranus, meanwhile is in Aquarius, and visible and observable in the ?morning.

Venus is still a morning star. She rises about two hours, or a little more, before the sun, and is bservers who will follow her example.

In the middle of the month all the five planets nown to the ancients will be simultaneously visi-an unusual occurrence.

Jupiter and Satum are morning stars like the thers, and are close to Mars. On the 13th Mars and Saturn are in conjunction, the former being Jupiter are still closer, only a sixth of a degre part.

The moon is in her first quarter at $11 \mathrm{~A}$. M. on the 7 th, full at $9 \mathrm{~A}$. M. on the 15 th, in her last quarter at $7 \mathrm{~A}$. M. on the 22nd, and new at $8 \mathrm{~A}$.
$\mathrm{M}$. on the 29th. During the month she passes near Saturn on the 24th, Mars and Jupiter on the 25th. Venus on the 27th, and Mercury on the following day. 